\title{
Modernização, políticas públicas e sistema de gênero no Brasil: educação e profissionalização feminina entre as décadas de 1920 e 1940*
}

\author{
Nara Azevedo ** \\ Luiz Otávio Ferreira***
}

\begin{abstract}
Resumo
Para um contingente importante de mulheres, sobretudo as de classe média urbana, as experiências de escolarização proporcionada pelas políticas sociais e, mais especificamente, pelas políticas educacionais implantadas isoladamente a partir dos anos 1920, que efetivamente se institucionalizaram na chamada era Vargas, foram em larga medida responsáveis por importantes mudanças no sistema de gênero, especialmente no que diz respeito à inserção profissional de mulheres no mundo acadêmico e científico. Este texto tem o propósito de rever uma interpretação relativamente consolidada na literatura sobre esse assunto, que tende a minimizar as conseqüências operadas por essas reformas no perfil educacional da população feminina.
\end{abstract}

Palavras-chave: Modernização, Políticas Públicas, Sistema de Gênero, Educação, Profissionalização Feminina.

\footnotetext{
" Recebido para publicação em agosto de 2006, aceito em setembro de 2006. Este trabalho é parte de um projeto realizado entre 2003-2005 - "Gênero e ciência: carreira e profissionalização no Instituto Oswaldo Cruz, Museu Nacional e Instituto de Biofísica (1939-1968)" - e financiado pelo CNPq.

** Professora do Programa de Pós-Graduação em História das Ciências da Saúde/Casa de Oswaldo Cruz/Fundação Oswaldo Cruz; Diretora da Casa de Oswaldo Cruz/Fundação Oswaldo Cruz. nazevedo@fiocruz.com.br

***** Professor do Programa de Pós-Graduação em História das Ciências e da Saúde/Casa de Oswaldo Cruz/Fundação Oswaldo Cruz; e professor adjunto da Universidade do Estado do Rio de Janeiro. lotavio@fiocruz.br
} 
Modernização, políticas públicas e sistema de gênero no Brasil

Modernization, Public Policies and Gender System in Brazil:

Women Education and Professionalization Between the 1920 and 1940 decades

\begin{abstract}
The social policies and, more specifically, the educational policies implemented in Brazil as of the 1920's in an isolated base, and effectively institutionalized during the Vargas era, encouraged a formal schooling process experimented by an important number of women, mostly by those from an urban middle class. These experiences were considerably responsible for relevant changes in the gender system, particularly in respect to women professional insertion in the academic and scientific world. This article aims to review a rather recognized interpretation in the specialized literature that tends to minimize the consequences produced by these reforms in the educational profile of the female population.
\end{abstract}

Key Words: Modernization, Public Policies, Gender System, Education, Women Professionalization. 
Dados demográficos recentes constatam o crescimento ininterrupto da participação de mulheres no sistema de ciência $e$ tecnologia (C\&T) brasileiro nos últimos trinta anos, notadamente nas instituições de ensino superior e de pesquisa. (Velho $e$ Prochazka, 2003; Rolemberg, 2001) Embora similar, esse quadro não é igual ao dos países desenvolvidos: de um lado, verifica-se uma progressão ligeiramente melhor das mulheres na escola, indicando certa debilidade de gênero, associada à persistência de separação masculino-feminino entre diferentes cursos e profissões, de outro, manifesta-se uma progressão interrompida e acidentada para mulheres e homens de estratos sociais e raciais subordinados. No mercado de trabalho, as profissões relacionadas ao magistério continuam sendo aquelas nas quais as mulheres são mais bem acolhidas: no final da década de 1990, a maioria das mulheres engajadas profissionalmente no magistério concentrava-se nos níveis fundamental e secundário de ensino. Contudo, no mesmo período, já era significativa a presença feminina no magistério de nível superior, sobretudo em áreas como a biologia, física, matemática e química, além das chamadas humanidades, letras, pedagogia, história. (Id.)

Se o grande desafio colocado por esses dados é o de explicar porque não se altera o padrão sexuado de carreiras escolares e profissionais, uma vez que os melhores resultados escolares são das mulheres (Id.), consideramos que o atual status educacional e profissional femininos, em certa medida, ainda repercute o efeito das reformas do sistema escolar brasileiro entre as décadas de 1920 e 1940, concomitante a um lento, mas perseverante, movimento de interesse por parte de mulheres, sobretudo aquelas pertencentes às classes média e alta urbanas, pelas profissões que requerem formação em nível superior, entre elas as ciências.

Este texto tem o propósito de rever uma interpretação relativamente consolidada na literatura sobre esse assunto, que tende a minimizar as conseqüências operadas por essas reformas no perfil educacional da população feminina. Pode-se dizer que o 
Modernização, políticas públicas e sistema de gênero no Brasil

estudo de Susan Besse sintetiza os principais argumentos dessa perspectiva ao afirmar que:

A meta do sistema educacional não era fomentar a emancipação intelectual, econômica e social feminina, mas mobilizar eficientemente as mulheres para promover a saúde física, a prosperidade econômica nacional e a estabilidade social e política. (...) Como mediadora entre o velho $e$ o novo, a educação feminina associava grandes doses de educação moral e de disciplina social à instrução em conhecimentos e habilidades básicas. A tarefa atribuída à mulher era "civilizar", "elevar" e "redimir" o mundo, não transformá-lo. (Besse, 1999:142)

Apesar de admitir que as novas condições sociais $e$ econômicas no pós-30, com a ascensão de Getúlio Vargas ao poder, favoreceram a expansão da educação feminina, apenas uma pequena elite se beneficiou no sentido de alcançar "a autorealização e a independência econômica por via da realização acadêmica e profissional" (Id.:129), subordinando-se as aspirações da maioria das mulheres ao controle da escola, que preservava a hierarquia de gênero ao diferenciar conteúdos para meninos e meninas. Para a autora, "os efeitos potencialmente radicais da expansão da educação foram atenuados pelo conteúdo da educação que as moças recebiam" (Id.), e que eram entendidos como aqueles que melhor as preparava para o casamento $e$ a maternidade. Ou seja, a função da educação era mais socializadora - no sentido da manutenção da domesticidade da mulher - do que libertadora. (Id.:124)

Tanto do ponto de vista de classe, quando dos significados sociais da educação feminina, segundo os quais as mulheres "continuariam a ser os baluartes da ordem social $e$ as guardiãs das relações sociais e de gênero tradicionais" (Id.:123), evidencia-se, para a autora, o caráter limitado das conquistas educacionais $e$, mais amplamente, do novo sistema de gênero que surgiu no decorrer da década de 1930, o qual foi moldado pela tradição 
autoritária do patriarcalismo e pela rígida estrutura hierárquica da sociedade brasileira. Se houve modernização dos papéis de gênero, esta, contudo, não abalou a estrutura de desigualdade, $e$ nem contribuiu para a emancipação das mulheres no que tange à dependência mental, emocional ou econômica que mantinham em relação aos homens. E conclui: "Na verdade, esses novos papéis (femininos), criando uma ilusão de mudança, mascaravam - e com isso ajudavam a perpetuar - a dominação masculina". (Id.:223)

A ênfase desses argumentos nas estruturas históricas de permanência encobre justamente o que interessa ressaltar, isto é, os aspectos mais dinâmicos desse processo, aos quais se pode imputar a transição do perfil educacional da população feminina que, em um curto período de tempo, do início da República à década de 40, evoluiu do analfabetismo para a formação em nível superior, direcionando-se, em número cada vez maior, para as profissões científicas que, sabemos, constituíam um monopólio masculino. ${ }^{1}$

O fenômeno de intensificação da escolarização feminina $e$ seus efeitos sobre as mudanças do sistema de gênero, que ocorreu nesse período, ainda requerem uma reflexão mais cuidadosa. Sem a pretensão de abranger os diferentes aspectos envolvidos nessa questão, tecemos algumas ponderações a partir da perspectiva mais geral segundo a qual, historicamente, assim como todos os dominados, as mulheres nem sempre foram vítimas ou sujeitos passivos; elas encontraram maneiras de se esquivar das prescrições sociais impostas, elaborando contra-poderes que podiam subverter os papéis aparentes nos espaços e tarefas a elas reservados. (Perrot, 2005:273) Nesse sentido, é possível supor que as oportunidades educacionais e profissionais, quaisquer que fossem, representaram naquele período uma brecha para a

1 Dados coligidos pela pesquisa "Gênero e ciência: carreira e profissionalização no Instituto Oswaldo Cruz, Museu Nacional e Instituto de Biofísica (1939-1968)", que identificou a expressiva presença de mulheres em carreiras científicas a partir dos anos 40 nas instituições de pesquisa do Rio de Janeiro. 
Modernização, políticas públicas e sistema de gênero no Brasil

emergência de um papel público para as mulheres, sinalizando não para uma "ilusão" ou farsa, mas para a mudança efetiva de seus papéis sociais. Isso porque entendemos a escolarização feminina como uma instância de mediação central entre a família $e$ as transformações culturais, políticas e econômicas que desde o início do século XX marcaram a transição do patriarcalismo rural para a sociedade urbana e industrial no Brasil.

A nova paisagem social forjou um novo estilo de vida urbano e favoreceu o aparecimento de novas sociabilidades, ensejadas pelos valores burgueses em construção. Novas identidades e diferenças sexuais emergiram. A iaiá do sobradoque nas palavras de Gilberto Freire era "um ser artificial, mórbido, uma doente, deformada no corpo para ser a serva do homem e a boneca de carne do marido" (Freyre, 2003:208) - se transmutou na mulher moderna, que surgiu após a I Guerra Mundial em busca de estudo e trabalho, freqüentando cinemas, teatros, parques $e$ praticando esportes. Conduzidas à esfera pública, as mulheres se tornaram consumidoras, assumiram profissões antes vedadas para elas, e passaram a lutar pelos direitos jurídicos e civis.

A crescente intervenção do Estado na família, abalando o poder patriarcal, favoreceu a construção de uma esfera pública das mulheres nas cidades, transformadas pela industrialização acelerada, pela imigração crescente e pelo vertiginoso crescimento populacional. Ali se reestruturou a ordem familiar, permitindo a conquista de novas funções e papéis sociais femininos. Moviam-se as fronteiras da vida privada para a esfera pública, rompendo o isolamento do mundo doméstico no qual as mulheres eram confinadas.

Nas primeiras seções deste texto, de forma breve, chamamos a atenção para a modernização burguesa no país, a qual se podem correlacionar as alterações no sistema de gênero, que apresenta ambigüidades homólogas as que caracterizaram aquele processo. Procuramos evidenciar certos aspectos das transformações culturais, emblematicamente expressas na geografia das grandes cidades do país - a capital da República, 
Rio de Janeiro, e São Paulo -, bem como nos hábitos e comportamentos de suas populações, por meio dos quais transparecem as mudanças dos papéis femininos $e$, por conseguinte, as expectativas sociais quanto à educação $e$ ao trabalho das mulheres. Os tópicos seguintes procuram novos sentidos para o fenômeno da escolarização feminina, focalizando as reformas educacionais que ocorreram nos anos 30 e 40, que resultaram da confluência da mobilização nacional de educadores, intelectuais, e do recente e combativo movimento feminista, com as políticas públicas implementadas pelo governo de Getúlio Vargas, notadamente após a instauração do estado autoritário corporativo em 1937.

Modernidade, modernização e sistema de gênero no Brasil

Ser moderno é viver uma vida de paradoxo e contradição. (...) Ser moderno é encontrar-se em um ambiente que promete aventura, poder, alegria, crescimento, autotransformação e transformação das coisas em redor mas ao mesmo tempo ameaça destruir tudo o que temos, tudo o que sabemos, tudo o que somos. (...) Ser moderno é fazer parte de um universo no qual, como disse Marx, "tudo o que é sólido desmancha no ar”. (Berman, 1986:12-15)

A famosa frase de Marx, que intitula o livro não menos notório de Marshall Berman, sintetiza admiravelmente o sentido da modernidade, que, como assinala o cientista norte-americano, constitui um tipo de experiência vital - de tempo, de espaço, de si e dos outros, das possibilidades e perigos da vida - compartilhada por homens e mulheres de todo o mundo desde o século XVI. (Id.:15) Há 500 anos um grupo grande e crescente de pessoas caminha através desse turbilhão, vivido quase sempre como uma ameaça radical à história de cada um, embora ela própria tenha desenvolvido uma rica história e uma variedade de tradições próprias. No século XIX - que para Berman marca a segunda fase da história da modernidade -, o amplo e moderno público, que se 
Modernização, políticas públicas e sistema de gênero no Brasil

instituíra após a revolução de 1789 e as convulsões sociais e políticas que a sucederam por toda a Europa, experimentou a sensação (material e espiritual) de viver em um mundo que não chegava a ser moderno por inteiro. Dessa dicotomia, de viver em dois mundos simultaneamente, emerge e se desdobra a idéia de modernismo e de modernização. Esta se faz acompanhar de uma atmosfera - de agitação e turbulência, aturdimento psíquico e embriaguez, expansão das possibilidades de experiência $e$ destruição das barreiras morais e dos compromissos pessoais, auto-expansão e autodesordem, fantasmas na rua e na alma que dá origem à sensibilidade moderna, altamente suscetível à consciência de que a vida moderna é radicalmente contraditória na sua base. Como assinala Marx:

A burguesia não pode sobreviver sem revolucionar constantemente os instrumentos de produção, e com eles todas as relações de produção, $e$ com eles todas as relações sociais. (...) Revolução ininterrupta da produção, contínua perturbação de todas as relações sociais, interminável incerteza e agitação, distinguem a era burguesa de todas as anteriores. (Marx apud Berman, 1986:20)

Esse impulso da burguesia de revolucionar permanentemente o mundo - que brota de suas próprias necessidades -, traduz exemplarmente o mundo moderno, onde tudo está impregnado de seu contrário, um mundo que, como diz Marx, "sob a superfície aparentemente sólida, se entrevêem oceanos de matéria líquida", onde "tudo que é sólido desmancha no ar". (Id.:22)

A lembrança desses célebres trechos é para referir que sentimentos similares - de desejo de mudança e de terror da desorientação e da desintegração do mundo em redor, da vida que se desfaz em pedaços -, também impregnaram a experiência da modernidade no Brasil, o que nos permite inscrevê-la na mesma torrente de transformações. Iniciado no final do século XIX, esse processo se desdobrou célere nas primeiras décadas do século XX, irradiando análogas energias transformadoras e 
experiências paradoxais. $\mathrm{O}$ moderno se efetivou com a industrialização da produção econômica, a constituição do mercado capitalista, a criação de novos ambientes humanos e a destruição dos antigos; acelerou-se o ritmo da vida; modificou-se o perfil demográfico, com uma acelerada urbanização, que atraiu vastas áreas rurais para a esfera de influência das cidades, além do contingente imigrante; instituiu-se um dinâmico sistema de comunicação e transporte; expandiu-se a burocracia e com ela o poder do Estado; os movimentos sociais se organizaram, desafiando a ordem política e, enfim, remodelaram-se os espaços físico e social.

Tanto São Paulo como Rio de Janeiro são cidades emblemáticas da configuração desse moderno concretizado na intensa urbanização, na introdução de hábitos e práticas de produção e consumo afeitas à nova ordem econômica capitalista. Como registra Sevcenko, esse processo, que se iniciou no final do século XIX, foi liderado pela

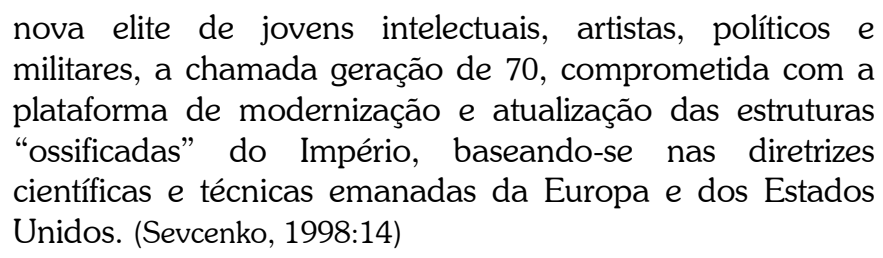

Baseando-se na riqueza recente gerada pela expansão da cultura cafeeira no sudeste do país, as novas elites pretendiam promover "uma industrialização imediata e uma modernização a qualquer custo" (Id.:15), sendo a reforma urbana do Rio de Janeiro um dos maiores símbolos do anseio republicano em "acertar os ponteiros brasileiros com o relógio global". (Id.:27)

No afã do esforço modernizador, as novas elites se empenhavam em reduzir a complexa realidade brasileira, singularizada pelas mazelas herdadas do colonialismo e da escravidão, ao ajustamento em conformidade com padrões 
Modernização, políticas públicas e sistema de gênero no Brasil

abstratos de gestão social hauridos de modelos europeus ou norte-americanos. Fossem esses os modelos da missão civilizadora das culturas da Europa do Norte, do urbanismo científico, da opinião pública esclarecida e participativa ou da crença resignada na infalibilidade do progresso. Era como se a instauração do novo regime implicasse pelo mesmo ato o cancelamento de toda a herança do passado histórico do país e pela mera reforma institucional ele tivesse fixado um nexo co-extensivo com a cultura $e$ a sociedade das potências industrializadas. A compreensão dos fenômenos do subdesenvolvimento $e$ das desigualdades inerentes ao sistema de trocas no mercado internacional levou um longo tempo para germinar $e$ adquirir uma significativa substância crítica entre as elites republicanas. E enquanto essa consciência crítica não amadurecia, prevaleceu o sentimento de vergonha, desprezo e ojeriza em relação ao passado, aos grupos sociais e rituais da cultura que evocassem os hábitos de um tempo que se julgava para sempre e felizmente superado. (Id.:27)

O enquadramento da sociedade e da cultura brasileiras na dinâmica global adquire, apesar da homogeneização que produz, a coloração local. O processo se efetiva não pela ruptura, mas pelo jogo da tensão com a tradição ibérica e patrimonialista: modernização sem revolução. (Wegner, 2000:48) Processa-se aqui uma civilidade - racionalização e impessoalidade - sem rompimento com a cordialidade, isto é, a pessoalidade das relações assinalada por Sérgio Buarque de Holanda (1995:146-47), que tem origem na esfera do íntimo, do familiar, do privado e, por conseguinte, avessa a uma ordem impessoal e ritualizada da vida social, característica do Estado burocrático, da civilidade e do individualismo burgueses. ${ }^{2} \mathrm{O}$ homem cordial, cuja socialização se

${ }^{2}$ A condição principal para o surgimento da civilidade é a quebra do localismo $e$ da intimidade. A contenção dos impulsos pessoais leva à criação de formas artificiais de sociabilidade, reconhecidas por todos, e à capacitação do indivíduo em lidar com seu exterior de forma mais neutra do ponto de vista afetivo. Assim, 
efetiva na família patriarcal, está impedido de distinguir entre um espaço pessoal e outro impessoal e rejeita os sistemas abstratos e coletivos:

Ele é incapaz de compreender a necessidade do ritualismo como algo que deve ser visto e compreendido por todos, $e$ a necessidade da distância e da artificialidade como condição para a socialização das pessoas em um mundo distinto do ambiente familiar. O localismo, o apego ao concreto, o sentimento que particulariza tornam a socialização cordial imprópria para a constituição do público. (Avelino Filho, 1990:11)

Conforme Avelino, para Buarque de Holanda, a transformação das estruturas sociais, com a imposição da urbanização e do cosmopolitismo, fortaleceram a civilidade, mas não determinaram o fim da cultura da personalidade, antes disso, ocorreu "um amalgamento entre a cordialidade e as instituições liberais que levava a uma utilização bizarra destas últimas". (Id.:13)

Em outros termos, trata-se de conceber a modernização como um ajustamento da tradição ao mundo moderno, por meio de um processo no qual uma elite política de "genuínas raízes ibéricas" (oligarquias rurais sem prévia socialização na gestão de uma economia capitalista moderna) abriu caminho no pós-30 para a alavancagem da industrialização e da modernização do Estado. (Vianna, 1997:8-9) Ou seja, a revolução burguesa brasileira teria se efetivado sem estabelecer uma ruptura com a tradição, não havendo incompatibilidade entre a velha ordem social $e$ a aceleração da acumulação capitalista. Em vez de contradição, uma complexa fusão entre ideais aparentemente opostos: "uma coalizão entre elites de origem cultural e social diversa conduziu a modernização do país" (Id.:19), realizando o americanismo por intermédio do iberismo, isto é, o gradual desenvolvimento da

forja-se o individuo civilizado, capaz de determinar de forma independente seus interesses e constituinte de um espaço público. (Avelino Filho, 1990:8) 
Modernização, políticas públicas e sistema de gênero no Brasil

igualdade mediante a conversão do atraso ibérico às luzes $e$ à civilização, sob a influência do modelo anglo-saxão implantado na América do Norte.

Contudo, se a americanização golpeou a aristocracia rural e diluiu a cordialidade, transmutando o patriarcalismo - próprio ao meio rural - em semipatriarcalismo nas cidades (Freyre, 2003:238), ela não trouxe consigo, automaticamente, a civilidade e nem novas instituições políticas (como a democracia liberal, a ética protestante e a ética do trabalho, presentes no contexto originário da ordem burguesa). Daí a particularidade e o dilema do caso brasileiro: o desmoronamento dos traços ibéricos e ao mesmo tempo a sua permanência. (Wegner, 2000:51)

De nosso ponto de vista, as relações de gênero assumiram características homólogas à modernização brasileira. Mas como seria diferente? Só se não levássemos em conta o caráter historicamente construído das diferenças entre os sexos, social e culturalmente determinadas. (Perrot, 2005; Scott, 1992) Nessa perspectiva, são compreensíveis os sinais contraditórios do processo de modernização do sistema de gênero, mantendo-se a subordinação da mulher ao poder masculino e, ao mesmo tempo, criando as condições institucionais - não ilusórias - que permitiram a alteração de seus papéis sociais, notadamente, no que concerne a sua participação na esfera pública.

\section{Família e gênero na cidade modernizada}

O principal cenário dessas mudanças foi a metrópole moderna, que se instituiu, paradoxalmente, enquanto um espaço de controle dos pobres, para o qual concorreram diferentes saberes - urbanismo, médico-higienista e da engenharia -, e como um espaço jurídico novo, fonte de ruptura e emancipação das malhas da servidão e da escravidão, no qual os homens se inseriram em uma rede de práticas contratuais e de relações 
formais, se opondo a antigas práticas e à noção de comunidade. ${ }^{3}$ Essa configuração as transformou em um local de liberação e de liberdade para as mulheres, bem como de modernização das relações sociais e sexuais. (Perrot, 2005:344) Nesse sentido, desde o final do século XIX, as mulheres procuraram um lugar para si em toda a parte, nas cidades, como observa Perrot:

Sair fisicamente: deambular fora de sua casa, na rua, penetrar em lugares proibidos - um café, um comício -, viajar. Sair moralmente dos papéis designados, construir uma opinião, passar da sujeição à independência: o que pode ser feito no público assim como no privado. (Perrot, 2005:280)

Embora possamos questionar quão urbanas eram as cidades latino-americanas, vis-à-vis Londres e Paris - as cidades-arquétipo da modernização - e, por conseguinte, sobrelevar as características locais, parece indubitável que, no Brasil, notadamente a partir da República, as cidades - enquanto espaço jurídico e político relativo aos direitos civis e espaço de opinião e de comunicação públicas (Perrot, 2005:262) - também promoveram progressivamente a constituição de uma esfera pública das mulheres.

A ampliação e o aprofundamento das formas capitalistas de produção modificaram as cidades brasileiras, nas quais um novo estilo de vida se impôs como resultado de um amálgama entre tradição e moderno. Política e economia convergiram, impondo uma nova geografia urbana - por meio de intervenções civilizadoras do espaço físico - e alterando o perfil demográfico,

3 A cidade moderna tornou-se um lugar de contestação radical, baseada em uma concepção de mundo expressa na declaração dos direitos do homem e do cidadão em cartas constitucionais. Ter direito à cidade significou a reivindicação do direito ao direito, ou seja, do acesso e da participação na sociedade contratual. (Bresciani, 2002:29) Nesse sentido, investiu-se de uma representação ambivalente: "local de origem de um caos avassalador e matriz de uma nova vitalidade emancipadora". (Sevcenko, 1992:18) 
Modernização, políticas públicas e sistema de gênero no Brasil

de que resultou uma paisagem social mais heterogênea, com a emergência de múltiplos papéis sociais e formas de sociabilidade distintas da tradição patriarcal. (Velho, 1995; Morse, 1995; Maluf e Mott, 1998)

A rápida urbanização alterou a feição colonial das cidades brasileiras, sobretudo Rio de Janeiro e São Paulo. Os dois maiores centros econômico-financeiros e políticos do país se tornaram os principais redutos urbanos do projeto civilizador republicano. Entre o último terço do século XIX e 1920, o Rio de Janeiro atravessou uma aprofunda alteração demográfica, com um acelerado crescimento populacional. A crise da lavoura do Vale do Paraíba expulsou do campo um grande contingente de mão-deobra e de ex-escravos, atraídos pelas oportunidades de trabalho na cidade, assim como ocorria com as expectativas de imigrantes, principalmente portugueses, que, em 1906, representavam 2/3 do total de estrangeiros residentes. ${ }^{4}$

Um aspecto relevante para a transformação da vida da cidade foi a reforma empreendida pelo prefeito Francisco Pereira Passos. Inspirada no modelo planificador francês de reforma urbana realizada por Haussmann em Paris no final do $\mathrm{XIX}^{5}$, a

\footnotetext{
4 Entre 1872 e 1890, a população e a densidade demográfica quase dobraram, sendo então a maior cidade do país, com cerca de 522 mil habitantes, e densidade populacional de 409 habitante por $\mathrm{Km}^{2}$. Abaixo dela, situavam-se São Paulo e Salvador com um pouco mais de 200 mil habitantes. Em 1906, a população da capital da República girava em torno de 811 mil habitantes, sendo a densidade populacional de 722 habitantes por $\mathrm{km}^{2}$. Constituía então uma cidade com grande proporção de população imigrante jovem e de sexo masculino: $31 \%$ dos habitantes tinham entre 15 e 30 anos, e $20 \%$ possuíam nacionalidade estrangeira. Os indivíduos de sexo masculino constituíam $57 \%$ da população total, elevando este percentual para $71 \%$ entre os estrangeiros. Em 1920, a cidade já ultrapassara a faixa de um milhão de habitantes, sendo a densidade populacional de 1030 habitantes por $\mathrm{km}^{2}$. (Araújo, 1993:30-31; Besse, 1999:16)

${ }^{5}$ Entre 1853 e 1870, o barão Georges Eugène Haussmann (1809-1891) nomeado por Napoleão III para o cargo de prefeito do Departamento de Seine (1863-1870) - empreendeu um plano de urbanização da cidade de Paris a partir
} 
intervenção procedeu a uma remodelação drástica no centro da cidade a partir de 1904, com a demolição de cortiços para abrir espaço para o alargamento de ruas e a abertura de avenidas, bem como para a construção de prédios públicos, parques, praças $e$ jardins arborizados com monumentos imponentes. A inauguração da Avenida Central em 1905 representou um marco da chamada regeneração da cidade. Ela tornou-se o símbolo da cidade civilizada, expressa entre outras novidades pelo cinema, o automóvel, o ônibus, os cafés, os clubes, os hotéis, as grandes companhias empresariais, o comércio de luxo. A Avenida Central, a Rua do Ouvidor - sua competidora na preferência do público -, e a Avenida Beira Mar intensificaram o prazer da flânerie e do footing, modificando-se as idéias e os hábitos da cidade. (Benchimol, 1992:210-231; Araújo, 1993:28, 327)

Se a capital da República se tornou a metrópole-modelo, ditando o sistema de valores e o modo de vida, São Paulo não ficou atrás, apresentando um crescimento notável no rastro da economia cafeeira. De núcleo periférico, com população flutuante, tornou-se o pólo econômico mais dinâmico do país e o centro político onde se decidiam os destinos da República. No período entre 1872 e 1890 a cidade duplicou a população, com um aumento espetacular de $269 \%$, voltando a crescer $141 \%$ entre 1900 e 1920. ${ }^{6}$ Atraídos por uma fabulosa acumulação de recursos, de oportunidades na indústria e no comércio ou vislumbrando a possibilidade de enriquecimento, multidões de famílias $e$ indivíduos acorreram a São Paulo, vindos de todas as partes do Brasil e de diversos pontos do mundo. (Sevcenko, 1992:108) Mais

do qual se tornou um modelo de metrópole industrial moderna imitado em todo o mundo. (Benchimol, 1992:192-194)

${ }^{6}$ De acordo com o primeiro censo realizado em 1872 a população era de 19.347, elevando-se para 64.934 habitantes em 1890. No início do XX, a cidade já contava com 270 mil moradores, cifra essa que dobrou em 1920, quando atingiu 579 mil, tornando a dobrar em 1934 ao alcançar 1.120 .000 habitante. Ou seja, no período de 62 anos (1872-1934), apresentou uma prodigiosa taxa crescimento populacional da ordem de 88\% ao ano. (Sevcenko, 1992:108-109) 
Modernização, políticas públicas e sistema de gênero no Brasil

de dois milhões de imigrantes europeus entraram no Estado entre 1888 e 1928 para trabalhar nas fazendas de café, migrando para a cidade parte desse contingente que possuía algum capital para se estabelecer como artesão, negociante ou empresário de vestuário e de processamento de alimentos. Os imigrantes forneciam mãode-obra barata para o número cada vez maior de fábricas que supriam de bens manufaturados os mercados locais em expansão, duplicando o valor do produto industrial do estado entre 1905 e 1915. Em 1920, São Paulo superou a capital federal como principal centro industrial, passando a competir como centro intelectual e cultural (Besse, 1999:16), no qual uma geração de jovens, que apareceu no pós-I Guerra Mundial e foi formada no caos urbano, passou a encarnar novas sensibilidades $e$ atitudes. (Sevcenko, 1992:32-33)

Os efeitos da urbanização acelerada sobre a vida dessas cidades se estenderam à família, organização social básica na qual se tornaram mais visíveis as mudanças culturais associadas aos valores burgueses em processo de constituição e expressos em novos padrões de comportamento familiar e de estilo de vida.

Uma nova forma de relacionamento entre a família e a cidade surgiu com a instauração da República, cujo programa político - de inspiração positivista e baseado nas idéias-chave de progresso e disciplina - privilegiava o binômio família/cidade como base de estruturação do estado nacional, sendo uma vista como a extensão da outra. Percebida como o sustentáculo do projeto civilizador (e normatizador) republicano, a família foi estimulada a adotar comportamentos melhor ajustados as novas realidades urbanas, marcadas pela diversidade de componentes. Nessa nova formação urbana, as formas mais tradicionais de solidariedade social, representadas pelas relações de grupos familiares, foram abaladas, estabelecendo uma tensão entre os traços patriarcais e as formas modernas de convivência familiar, que substituem o compromisso com os laços de sangue ou com a comunidade pelos interesses individuais. (Araújo, 1993:30-34) 
$\mathrm{Na}$ capital da República - que se tornou o palco de visibilidade das transformações em marcha pelo mundo e de sua atuação em território nacional, daí ser reconhecida como vitrine do país (Sevcenko [a], 1998:522) -, a interação entre família e urbanização induziu a novos padrões de comportamento, com o abalo de valores e atitudes tradicionais. Para Rosa Maria Barbosa Araújo (1993:25), o ponto estratégico de mudança foi dado pela atração da família pela rua, especialmente em busca de lazer $e$ recreação, "produzindo uma atmosfera cosmopolita pluricultural". Instituiu-se um novo estilo de vida, que implicou a adoção de formas burguesas de desfrutar as atrações urbanas, ou formas populares de criar modos de divertimento barato. Sintetiza a autora seu principal argumento:

a identidade cultural do Rio de Janeiro foi determinada por um novo comportamento social na medida que a família atravessou a fronteira do espaço privado da casa para o espaço público da rua, descomprimindo-se os limites entre essas duas esferas. (Araújo, 1993:283-84)

O processo de urbanização ao final do século XIX alterou a conotação atribuída à rua: de lugar ameaçador aos valores morais e a solidez da família como instituição, a espaço de exercício da civilidade almejada pelos republicanos. A inauguração da Avenida Central em 1905 - ápice do processo civilizador - mudou hábitos e costumes, intensificou a freqüência e o gosto do passeio familiar ao ar livre e promoveu interação social, valorizando esse tipo de

7 A autora adota a interpretação desenvolvida por Roberto Da Matta - inspirada em Gilberto Freyre - a respeito da oposição simbólica entre essas duas esferas: enquanto a casa significa a estabilidade, controle, calma, afeto, e respeito, a rua simboliza a imprevisibilidade, a desorientação, a novidade, a decepção a permissividade. (Matta, 1979) Conforme registrou Gilberto Freyre, os burgueses de sobrado raramente saíam às ruas, de dia ou de noite. Tratava-se de um sinal de distinção em relação ao restante da população escrava e de trabalhadores brancos, que exerciam seus ofícios na cidade ou então que tinham outra procedência como judeus e ciganos. (Freyre, 2003:146) 
Modernização, políticas públicas e sistema de gênero no Brasil

lazer, como ocorreu em outras cidades do mundo que também sofreram remodelações análogas. (Araújo, 1993:326)

$\mathrm{Na}$ outra maior metrópole brasileira da época, São Paulo, ocorreu fenômeno similar, como registra Nicolau Sevcenko. Ali o cosmopolitismo urbano provocou o estilhaçamento das referências estáveis e das tradições totalizantes, promovendo tensões nos padrões culturais vigentes, com a emergência de manifestações ritualizadas de massa como o carnaval, o esporte, o trânsito, comícios populares, entre outras. O imperativo da ação - novo código irradiador das significações na nova sociedade em formação - requeria das pessoas o engajamento físico, que tornava um despropósito ridículo, por exemplo, o antigo hábito de repousar nos fins de semana:

Todos para a rua: é lá que está a ação. Não é que repousar não seja mais viável, é que se tornou obsolescência, caduquice. Não é descansando que alguém se prepara para a semana vindoura, é recarregando as energias, tonificando os nervos, exercitando os músculos estimulando os sentidos, excitando o espírito. (Sevcenko, 1992:33-34)

Apesar das resistências à nova ordem cultural - reconhecida como uma força alienígena amoral, uma epidemia a ser combatida ou pelo menos controlada se o mal fosse inevitável, como parecia a muitos -, se impõe, sob o epíteto genérico de diversões, toda uma nova série de hábitos físicos, sensoriais $e$ mentais exercitados no fim de semana, mas também incorporados crescentemente à vida cotidiana, tais como esportes, danças, cinemas, chás, excursões, entre outros. Embora muitos desses hábitos já existissem desde o começo do século, nos anos 20 essas experiências adquiriram uma significação especial, constituindo a fonte de uma nova identidade e de um novo estilo de vida. Estes contaram com a adesão maciça dos jovens, que conquistaram um súbito prestígio social exatamente por encarnarem as novas práticas e mentalidades. (Id.:35) 
Nesse tempo marcado por um novo relacionamento entre os universos familiar $e$ urbano evoluíram os costumes $e$ as mulheres ganharam o espaço público. Concorreu para tanto, o advento de tecnologias que transfiguraram o meio urbano, notadamente a iluminação a gás e o serviço regular de bondes, permitindo que as mulheres da elite adquirissem maior autonomia, e se aventurassem a sair de casa, com segurança, conforto e facilidade, em busca de lazer. Por volta de 1910, no Rio de Janeiro, elas já andavam sozinhas na rua, iam às compras no centro da cidade (o footing), freqüentavam teatro, cinema, restaurantes, festas, clubes esportivos (inicialmente como espectadoras $e$ depois como atletas ${ }^{8}$ ) e cumpriam uma programação social eminentemente feminina: chás vespertinos, visitas a parentes e amigas. (Araújo, 1993:87; Besse, 1999:19; Sevcenko, 1992:50)

A intensificação da vida social, com a comercialização do lazer, transformou as mulheres da elite em consumidoras de diversão pública, juntando-as aos homens de sua classe nessas atividades, favorecendo assim o apagamento das diferenças de comportamento regidas pelo sexo. Um outro aspecto importante que convergiu para o mesmo efeito $e$, por conseguinte, para a mudança de costumes entre as mulheres desse extrato social foi a moda, que se tornou uma motivação crescente no universo feminino. Como assinala Besse:

Enquanto a moda do século XIX havia acentuado a diferença entre os sexos, refletindo seus distintos papéis sociais $e$ a aplicação rígida de um duplo padrão de moralidade, as modas do pós-guerra apagaram

\footnotetext{
8 Um símbolo emblemático dessa modernidade urbana foi Maria Lenk (1915- ), que começou a nadar aos 15 anos e aos 28 anos já competia no rio Tietê. Ela se tornou o primeiro grande ídolo feminino do esporte paulista. Considerada a pioneira da natação brasileira, foi a primeira mulher sul-americana a participar de uma Olimpíada, a de Los Angeles, em 1932, embora nunca tenha sido agraciada com uma medalha olímpica. (Sevcenko, 1992:71)
} 
Modernização, políticas públicas e sistema de gênero no Brasil

\begin{abstract}
subitamente essas distinções. No século XIX os homens vestiam-se rigorosamente de cores escuras, usavam barba $e$ bengala, realçando sua seriedade e competência. As mulheres usavam roupas extremamente enfeitadas $e$ incômodas, acentuando sua submissão e dependência. Enquanto os homens faziam o papel de atores públicos agressivos, a aparência das mulheres indicava seu status de ornamentos passivos e desprotegidos. (Besse, 1999:31) ${ }^{9}$
\end{abstract}

Concepções inovadoras de moda apareceram na década de 1920, estabelecendo um novo padrão de beleza. Seguindo a propaganda difundida pelo cinema, por catálogos e revistas européias e norte-americanas, que despertavam fascínio entre as mulheres, as jovens abandonaram comportamentos e modas antigas para adotar novos trajes, com a utilização de tecidos mais leves e roupas práticas, e uma nova aparência, evidenciada de diferentes maneiras: encurtamento das saias, cabelos curtos à la garçonne, escurecimento de cílios e pintura das sobrancelhas, uso de ruge nas faces e de lábios vermelhos, além de outros traços modernos de comportamento como o uso de maillots que deixavam braços e pernas escandalosamente expostos, ou ainda o hábito de fumar em público e falar gírias. (Besse, 1999:32; Araújo, 1993:83; Sevcenko, 1992)

Se a urbanização concorreu para as redefinições das normas de gênero, das quais emergiu a mulher moderna - reconhecida de modo contraditório como um símbolo do progresso e ao mesmo tempo como uma ameaça à família -, outros processos interdependentes relacionados aos padrões burgueses de interação social foram determinantes para a metamorfose da família e para o surgimento de um novo estilo de vida para a mulher. O primeiro refere-se às transformações de ordem política

\footnotetext{
9 Hobsbawn já havia observado o mesmo fenômeno nos países europeus, nos quais "as modas da liberação feminina pós-1918 tiveram suas pioneiras nas avant-gardes pré-guerra, florescendo nos quarteirões boêmios das grandes cidades". (Hobsbawn, 1988:306)
} 
Nara Azevedo e Luiz Otávio Ferreira

que limitaram progressivamente a autoridade masculina. A intervenção crescente na família por parte do Estado nacional, em seu processo de constituição desde o século XIX, reequacionou o poder absoluto do homem sobre o grupo familiar; o Estado passou a normatizar a vida social em diversos aspectos como a administração da justiça, a segurança, a regulamentação dos direitos de propriedade, além de outras instituições extrafamiliares que assumiram muitas das funções da família patriarcal extensa, como a medicina e a escola. (Freyre, 2003:237-239; Besse, 1999:19; Araújo, 1993:45-46) Apesar disso, o pátrio poder continuou a ser assegurado no plano jurídico, como evidenciado no Código Civil de 1916, segundo o qual a mulher permanecia subordinada a autoridade do pai e do marido, o que a impedia de gerenciar seus próprios bens econômicos, de exercer uma ocupação sem a autorização previa de um e outro (Hobsbawn, 1988278-281; Louro e Meyer, 1993:48-49) e de desfrutar o direito de voto.

Outros elementos da nova ordem burguesa e urbana a pressionar a supremacia do poder masculino na esfera familiar foram as transformações sócio-econômicas capitalistas, a partir das quais a família perdeu a função de unidade básica de produção, assumindo o caráter de unidade de consumo dos bens produzidos fora do lar. Com isso, o trabalho feminino doméstico passou a ser desvalorizado, porque perdeu sua conexão direta com a esfera da produção econômica, fortalecendo a dependência da mulher em relação ao homem e modificando seu papel e status na família. Porém, contraditoriamente, essas mudanças que solaparam o papel produtivo das mulheres também conduziram ao seu reconhecimento como o lócus da autoridade moral da sociedade. A emergência do culto da domesticidade, segundo o qual o lar passou a adquirir um conjunto de papéis de ordem social, política, religiosa e emocional e que se verificou no Brasil desde meados do século XIX - quando se iniciou o processo de consolidação do Estado nacional -, valorizou e redefiniu o espaço doméstico, como 
Modernização, políticas públicas e sistema de gênero no Brasil

resultado de sua interpenetração com a esfera do político. ${ }^{10}$ Por outro lado, essas mesmas mudanças produziram efeitos mais amplos $e$ inesperados, determinando novas oportunidades educacionais e profissionais, notadamente para as mulheres provenientes das camadas urbanas médias e altas. A expansão progressiva da economia de mercado no país induziu essas mulheres ao mundo do trabalho não doméstico, apesar da resistência masculina. Esse movimento crescente da população feminina em direção aos setores de produção de bens e serviços alterou significativamente as condições da vida familiar, embora esse fenômeno não a tenha situado numa posição social equivalente a do homem. (Araújo, 1993:73; Besse, 1999:20, 143-145)

Apesar do aparecimento de um discurso crítico relativo à nova posição social e econômica da mulher, a urbanização e o novo estilo de vida burguês instigaram a mudança de hábitos $e$ costumes familiares, movendo, por conseguinte, as normas de gênero no sentido da alteração dos papéis femininos e de novos padrões de comportamento, mediante a diversificação das formas de socialização, notadamente o trabalho e a educação (Araújo, 1993:64-65, 87; Besse, 1999:62), sendo esta última um dos indicadores mais significativos da mudança da posição social das mulheres nos países ocidentais desde o final do século XIX. (Hobsbawn, 1988:286) No Brasil, tanto no campo do debate cultural mais amplo, e relacionado ao discurso nacionalista que emergiu após a I Guerra Mundial, quanto na dimensão da ideologia corporativa forjada no Estado Novo, segundo a qual as massas urbanas deveriam ser incorporadas à ordem social por meio do trabalho, a educação em geral e, em particular, a educação feminina se tornaram um tema de debate público nos anos 20 e 30.

\footnotetext{
${ }^{10}$ Nos Estados Unidos esse fenômeno forjou-se no contexto da revolução americana, quando se interpenetraram o político e o doméstico na luta pela resistência ao poder britânico. O lar tornou-se decisivo para o sucesso da nação, $e$ às mulheres, cuja educação passou a ser considerada, foi atribuído o papel de mães da república. (Louro e Meyer, 1993:48)
} 
Nara Azevedo e Luiz Otávio Ferreira

\section{A acelerada escolarização feminina}

O crescimento notável do ingresso de mulheres na escola durante as primeiras décadas da República constitui um fato historicamente relevante para compreendermos como foram forjadas as condições culturais e institucionais que propiciaram às mulheres o acesso à carreira científica nas universidades $e$ instituições de pesquisa. A partir do final da década de 30 verificase a presença de mulheres em todos os níveis escolares, sobretudo nos cursos superiores, firmando-se esta como uma tendência crescente e constante daí em diante.

Até a instauração da República a grande maioria da população era analfabeta, as mulheres em maior proporção. Em 1827, a primeira lei imperial sobre ensino determinou a gratuidade da instrução primária a todos os cidadãos, estabelecendo a criação de escolas para meninas, nas quais aprenderiam a ler e a escrever, fazer as quatro operações aritméticas, alem de costurar e bordar. A instrução secundária seria oferecida apenas para a população masculina, da qual se esperava que prosseguisse os estudos em nível superior, o que não era racional nem compatível com a posição da mulher, uma vez que não se esperava dela o ingresso no mercado de trabalho. Ademais, de acordo com o Ato Adicional de 1834, o ensino secundário ficaria a cargo da União, enquanto a instrução primária seria responsabilidade da administração municipal. Na Capital do Império o número de escolas femininas era inferior ao de escolas masculinas, que possuíam corpo docente mais qualificado. Somente em 1880 foi criada a primeira escola normal, visando a qualificação profissional de quadros para o ensino primário. Tanto esta quanto às escolas particulares para meninas de nível secundário não se equiparavam ao Colégio Pedro II, freqüentado por uma clientela exclusivamente masculina.

A diferenciação por sexo foi assim uma característica da educação durante o Império. A instrução feminina manteve-se precária e rudimentar, fosse nas escolas públicas, nas particulares 
Modernização, políticas públicas e sistema de gênero no Brasil

ou nos educandários destinados a meninas carentes. ${ }^{11}$ Com a República esse quadro começou a se transformar, observando-se que um número crescente de mulheres começou a buscar a educação como meio de garantir a segurança econômica e o status social. (Besse, 1999:127) Nesse sentido, a constituição republicana foi determinante ao separar a Igreja do Estado $e$, por extensão, a educação católica da educação laica, que impulsionou a ampliação da rede pública de escolas primárias mistas. Apesar de o ensino secundário continuar a ser oferecido somente por escolas particulares (a maioria mantida por ordens religiosas) ou com tutores ${ }^{12}$, a consagração da educação laica foi um fator decisivo para a mudança da educação feminina ao relativizar a tutela católica, cujo ensino rejeitava a transmissão de conhecimento científico, priorizando os princípios morais e de preservação da família. Outro aspecto não menos importante foi a difusão da crença segundo a qual a educação e o trabalho femininos constituíam uma necessidade para o progresso $e$ a civilização do país. O mundo moderno requeria uma redefinição da função materna, que deveria deixar de se confinar ao lar para se estender à vida pública. Para tanto, a mulher deveria receber na escola um treinamento que as preparasse para conduzir a

${ }^{11}$ Embora o ensino primário tivesse sido assegurado desde uma lei federal aprovada em 1827, não havia professoras qualificadas em número suficiente para compor o corpo docente das escolas para meninas, considerando-se inapropriado que professores homens dessem aulas para elas. Segundo o Censo de 1872 apenas 18 mulheres na cidade de São Paulo e 313 no Rio de Janeiro trabalhavam como professoras do ensino primário e secundário. Somente quando a co-educação se tornou obrigatória em 1879 nas escolas públicas primárias, e, quando, na década de 1880 , as escolas normais mistas foram criadas de maneira ampla e definitiva para formar professores primários e secundários, é que a educação primária feminina se expandiu. (Besse, 1999:125) ${ }^{12} \mathrm{O}$ colégio Pedro II no Rio de Janeiro era a escola secundária de maior prestígio do país, a única a conceder diploma que qualificava automaticamente os formandos a ingressar em instituições de ensino superior. Só veio a se tornar mista em 1922. Ou seja, apesar das instituições de ensino superior terem sido franqueadas às mulheres em 1879 , poucas estavam aptas a obter o preparo acadêmico necessário para serem aprovadas nos exames de ingresso. 
Nara Azevedo e Luiz Otávio Ferreira

educação das crianças segundo os paradigmas científicos da higiene e da psicologia.

Tais mudanças institucionais e ideológicas se expressavam em indicadores que mostravam que na capital federal, entre 1890 e 1920, o percentual de mulheres alfabetizadas elevou-se consideravelmente em relação ao total da população feminina: se em 1890 perfaziam 43,53\%, e em 1906, 46,01\%, em 1920 aumentou para 55,8\%. (Besse, 1999:130) Em São Paulo, se em 1890 a situação era de desvantagem em relação ao Rio de Janeiro, com uma taxa de alfabetização de 22,1\%, em 1920 se equiparou com um índice de $52,1 \%$ da população feminina alfabetizada. (Id.:126)

Um dos poucos estudos que permite avaliar as transformações relacionadas à escolarização feminina mostra que, no estado de São Paulo, unidade da federação que em 1940 apresentava um índice de alfabetização bem superior (52\% da população) à média nacional (38\% da população), a distância entre homens alfabetizados $e$ mulheres alfabetizadas não era tão expressiva. A vantagem do sexo masculino era ligeira, $29 \%$ contra $22 \%$. O maior desnível de escolaridade entre homens e mulheres era encontrado na conclusão de cursos de nível superior. Apresentando percentual ligeiramente maior do que a média nacional (9\%), as mulheres paulistas representavam $11 \%$ do total da população que havia concluído o curso superior, dados que ainda não refletiam o impacto da criação da Universidade de São Paulo. Ainda que os dados estatísticos não devam ser interpretados e comparados literalmente, mudanças significativas são observadas no confronto dos resultados relativos à escolarização feminina apresentados pelos recenseamentos realizados em 1940 e 1970. Se em 1940, no estado de São Paulo, a maioria das mulheres era analfabeta, em 1970 mais de 2/3 da população feminina era alfabetizada. Com relação à escolarização de nível superior o salto quantitativo foi ainda mais expressivo. Enquanto em 1940, as mulheres representavam um pouco mais que $10 \%$ dos que possuíam diploma de curso superior, em 1970 o 
Modernização, políticas públicas e sistema de gênero no Brasil

percentual havia quadruplicado, isto é, aproximadamente $40 \%$ dos que haviam concluído com sucesso este nível de escolarização eram mulheres. (Tupy, 2002:14-15)

Se do ponto de vista estatístico é inegável a alteração dos níveis de escolarização das mulheres, ainda restam muitas dúvidas sobre o significado sociológico da intensificação da educação feminina. Susan Besse afirma que o efeito potencialmente transformador do maior acesso à educação propiciado pela expansão do sistema escolar, observada a partir da década de 1920, foi neutralizado pelo "conteúdo da educação" destinada nomeadamente às mulheres, visando essencialmente prepará-las para o casamento e a maternidade. Mesmo considerando que as novas condições econômicas e sociais, decorrentes da intensificação da urbanização e da industrialização, tenham favorecido a expansão da educação feminina, a "significação social" da elevação do nível de escolaridade das mulheres foi contida pelo fato de não terem sido seriamente questionadas as relações de gênero tradicionais. (Besse, 1999:122-143) Nesse caso, certos aspectos inovadores relacionados à educação feminina, induzidos pelas políticas educacionais - tais como co-educação, acesso irrestrito ao ensino secundário, formação profissional em nível técnico, reformulação pedagógica da escola normal e experiências de formação para o magistério em cursos de nível superior -, não deveriam ser seriamente considerados.

Políticas de educação e políticas de gênero

É sabido que as políticas educacionais então implementadas, particularmente aquelas postas em prática na chamada era Vargas (1930 a 1945), devem ser compreendidas em uma perspectiva mais ampla que as considere como parte de um conjunto de políticas sociais orientadas simultaneamente para a (re)organização do trabalho, da família, da educação (Gomes, 2003) e, podemos acrescentar, da saúde. Abordada dessa perspectiva, a questão da escolarização e profissionalização 
feminina adquire contornos que extrapolam a esfera restrita da educação escolar para se inscrever na dinâmica das mudanças sócio-culturais em curso.

Os anos 1920 são apontados como o contexto no qual foram formuladas as idéias fundamentais e empreendidas as ações pioneiras que lançaram as bases institucionais da moderna organização escolar brasileira, consolidadas nos anos 30 e 40 do século XX. O que destacou a última década da Primeira República das que a antecederam foi justamente "a preocupação bastante vigorosa em pensar e modificar os padrões de ensino e cultura das instituições escolares, nas diferentes modalidades e nos diferentes níveis". (Nagle, 2001:134) Impulsionada pela Associação Brasileira de Educação (ABE) - criada, em 1924, no Rio de Janeiro na Escola Politécnica, por um grupo de engenheiros, médicos, advogados, políticos, professores, liderados pelo educador Heitor Lyra da Silva -, a escolarização da sociedade tornou-se motivo de mobilização social e objeto de políticas públicas formuladas $e$ postas em prática em algumas das mais importantes unidades da federação - São Paulo, Minas Gerais, Ceará, Bahia e Distrito Federal -, bem como no âmbito do Governo Federal, então responsável pela gestão do ensino secundário e superior.

Embora tenha sido um movimento de elites, nunca houve total unanimidade entre os adeptos e militantes da causa educacional a respeito da finalidade social da escolarização. $\mathrm{Na}$ verdade, isso foi motivo de intensa disputa entre intelectuais e políticos de orientação liberal, católica, positivista, socialista, nacionalista, modernista e feminista. (Hanner, 2003:115-181) Ao invés de uma inofensiva "batalha de idéias" ocorreu uma luta ferrenha pelo controle simbólico e pelo poder decisório sobre os rumos de um amplo projeto de reforma social no qual a escolarização da população ocupava um lugar estratégico. (Carvalho, 1998:53-132)

Dedicadas à reformulação $e$ a universalização da escolaridade, as políticas públicas eram concebidas não apenas para ampliar a rede escolar, melhorar suas condições de 
Modernização, políticas públicas e sistema de gênero no Brasil

funcionamento e estabelecer uma estrutura técnico-burocrática responsável pela sua administração, mas, sobretudo, deveriam substituir o antigo ideário pedagógico "pelos princípios da nova teoria educacional representada pelo chamado escolanovismo". (Nagle, 2001:244) Sob essa denominação abrigava-se um conjunto bastante heterogêneo de concepções e práticas relativas ao funcionamento $e$ as atribuições sociais da escola. No entanto, a "escola nova no Brasil sugere a convergência entre reforma educacional e reforma social". (Vidal, 2003:275) A interseção entre reforma educacional e reforma social é mais evidente, sobretudo, quando se observa o lugar estratégico atribuído à escola na conformação do espaço e do estilo de vida urbano como signos da modernidade. (Nunes, 1993)

As políticas educacionais ao mesmo tempo em que cogitavam a escolarização universal em nível primário também propunham formas especializadas de escolarização, definidas conforme a classe social e/ou o gênero dos indivíduos. Deste modo, ao lado das modalidades tradicionais de ensino (primário, secundário e superior) desenvolveu-se um outro ramo dedicado à formação profissional, que consistiu o "primeiro sistema educacional de abrangência nacional" dotado de propósitos comuns, regulado por uma mesma legislação e subordinado a mesma autoridade administrativa e pedagógica. (Cunha, 2000:66) Esse sistema contemplava escolas profissionais para mulheres, oferecendo cursos que incluíam a capacitação técnica em atividades domésticas, comerciais, artísticas e pedagógicas.

Ao propor esse modelo de educação escolar orientado às mulheres, os formuladores das políticas públicas tinham em mente a necessidade, para eles cada vez mais flagrante, de "preparação" da população feminina para o desempenho de novas funções na vida pública e privada, em uma ordem social que desejava afastar-se de seu passado patriarcal e escravocrata. Nos grandes centros urbanos, sobretudo Rio de Janeiro e São Paulo, a vida social cada vez mais se organizava em termos de uma "economia de mercado", na qual o trabalho, o consumo, a competição, a 
mobilidade, o lazer e o prazer assumiam valor destacado. Para que estivessem capacitadas a desempenhar seus novos papéis na "sociedade moderna", as futuras gerações de mulheres deveriam receber na escola a socialização necessária para se tornarem "educadoras sociais", isto é, mães, esposas e/ou trabalhadores preparadas tanto para conduzirem a administração da vida doméstica, quanto para dirigir a educação escolar, a educação sanitária, a assistência social segundo preceitos técnicocientíficos. ${ }^{13}$

Embora se considere que esse tipo de escolarização reiterasse os compromissos ideológicos de gênero, preparando apenas futuras mães e esposas (Louro, 1993: 45-57; Vidal, 1996:3035), as experiências desenvolvidas em escolas de formação profissional podem ser interpretadas como um laboratório social no qual foram vivenciados novos papéis que projetavam as mulheres no espaço público enquanto profissionais. Assim, o novo papel social atribuído ao gênero feminino, que associava a domesticidade à vida pública, algumas vezes chamada de "maternidade científica" (Apple, 1987; Perrot, s/d) ou de "maternidade social" (Besse, 1999; Vidal e Rodrigues, 2004), não consistia pura e simplesmente a reiteração dos atributos "naturais" femininos de mãe e esposa. Nessa perspectiva, a escolarização do doméstico implicava a reinvenção das tarefas atribuídas às mulheres no sentido de sua conversão em tipos específicos de trabalho $e$, conseqüentemente, sua transformação em várias espécies de atividades profissionais. Ou seja, ao mesmo tempo em que se difundia uma nova representação da "dona-de-casa" e da "mãe de família" também se promovia a efetiva escolarização $e$ profissionalização de parcela da população feminina em uma escala sem precedentes. Além de "boas futuras mães e esposas", as escolas de formação profissional também lançavam na esfera

\footnotetext{
${ }^{13}$ As chamadas profissões sanitárias são um exemplo de "educadoras sociais" cujas funções associavam a domesticidade à vida pública. Sobre o tema ver Rocha, 2005.
} 
Modernização, políticas públicas e sistema de gênero no Brasil

pública operárias, peritas ou professoras especializadas em técnicas industriais, comerciais, artísticas e domésticas, fato até então inédito.

\section{Magistério e profissionalização}

Um bom exemplo disso foi o magistério no ensino profissional que constituiu uma alternativa efetiva de educação $e$ trabalho para as mulheres. Na única instituição dedicada à formação de professores para este ramo de ensino em funcionamento no país - a Escola Normal de Artes e Ofícios Wenceslau Braz, sediada na capital da República - se observou em 20 anos, de 1917 a 1937, que "os alunos eram predominantemente do sexo feminino, numa proporção superior a 50\%", tendo o número de matrículas oscilado entre o mínimo de 122 ao máximo de 459 ao ano. Sintomaticamente, o fato foi registrado negativamente por Celso Suckow da Fonseca ${ }^{14}$, uma das lideranças masculinas do ensino profissional brasileiro, que lamentava "a preponderância do elemento feminino" e avaliava que isso teria "prejudicado o principal fim da instituição" que supostamente seria a formação de professores dedicados ao ensino profissões consideradas masculinas.

As moças que aí se matriculavam procuravam titular-se como professoras de datilografia, de modas e de economia doméstica, embora fosse muito mais necessário às varias escolas de aprendizes artífices o preparo de pessoal capaz de ensinar trabalhos em madeira, metal ou eletricidade. (Cunha, 2000:85)

Talvez a industrialização ainda não tivesse intensidade suficiente para sustentar a demanda continuada de docentes

\footnotetext{
${ }^{14}$ Sobre a trajetória do engenheiro Celso Suckow da Fonseca, ver o verbete de autoria de Maria Ciavatta Franco e Rebeca Gontijo em Fávero e Medeiros Britto, 2002:253-258.
} 
masculinos especializados em profissões industriais. Todavia, o que merece ser salientado é que a majoritária participação feminina na composição do magistério do ensino profissionalizante sugere um interesse, por parte das mulheres, maior do que se costuma supor, nessas oportunidades disponíveis de educação e trabalho.

A afluência de mulheres foi ainda muito mais intensa no caso do tradicional ramo de ensino dedicado à formação para o magistério, cujo lócus institucional é a chamada escola normal. Ali puderam ser notados mais nitidamente os efeitos da intensificação da escolarização promovida entre os anos 1920 e 1940 para a recomposição dos papéis de gênero.

De acordo com a ideologia escolanovista, as preocupações de cunho nacionalista, as recomendações de disposição eugênica $e$ higiênica, as exaltações em favor da ciência e da técnica deveriam ser acompanhadas da difusão de um ideário educacional que exigia a preparação de um novo tipo de professora socializada segundo os princípios da "moderna pedagogia". A reinvenção institucional e pedagógica da escola normal tornou-se uma tarefa urgente. A escola normal sofreu "transformações mais profundas que as escolas primárias". (Nagle, 2001:281) A formação para o magistério deixou de ser uma simples extensão da escolarização primária, passando a exigir para o ingresso uma preparação mais apurada, obtida em cursos complementares, que constituíam etapas intermediárias e obrigatórias entre a escola primária e a normal. Além disso, se aprofundou a profissionalização do magistério ao se definir um currículo de caráter científico-experimental com a inclusão, no plano de estudos, de disciplinas como a anatomia e fisiologia humanas, higiene, pedagogia, história da educação, sociologia e, especialmente, psicologia.

A reinvenção da escola normal nesses termos veio associada à intensificação da feminização do magistério. Embora não houvesse no ideário dos reformadores nenhuma convocação explícita de gênero, no ambiente ideológico da época já se havia 
Modernização, políticas públicas e sistema de gênero no Brasil

estabelecido tal associação. (Vidal e Rodrigues, 2004:95) Embora retrospectivamente se possa concluir que a feminização acarretou a precarização do trabalho, o rebaixamento salarial $e$ a estratificação social da carreira, tornando o magistério uma "semiprofissão", cuja identidade e status social estaria definido segundo relações de gênero e de poder vigentes, tal como a enfermagem (Bruschini e Amado, 1988; Dermartini e Antunsa, 1993; Werle, 2005), é possivel supor que a identificação entre a mulher $e$ a prática do magistério, em um contexto de explícitos investimentos institucionais e simbólicos dirigidos à escola normal, funcionasse como um atrativo crescente e consciente para uma parcela específica da população feminina demandante de educação e profissionalização. Foi o que ocorreu entre 1932 e 1937 no Instituto de Educação, cuja experiência sui generis foi liderada por Manoel Lourenço Filho e Anísio Teixeira, que ocupava o cargo de diretor da Instrução Pública do Distrito Federal.

Pela primeira vez a formação para o magistério se fazia em um curso de nível superior, já que o ingresso na Escola de Professores do Instituto de Educação exigia a passagem obrigatória pelo curso secundário oferecido na própria instituição. Equiparada ao Colégio Pedro II, a escola secundária do Instituto de Educação oferecia ao seu corpo discente, constituído majoritariamente de moças, a possibilidade de ingresso em qualquer curso de nível superior. Essa oportunidade inédita de escolarização e profissionalização, fundada em princípios científicos extraídos da biologia, higiene, pedagogia, psicologia e sociologia, foi acessível a uma clientela oriunda em sua maioria de classe média urbana residente em bairros cariocas tradicionais.

As moças que procuravam a Escola de Professores, em média, tinham 20 anos. As mais novas chegavam aos 18 anos, idade mínima exigida. As mais velhas aos 26, 27, 28 anos. Geralmente procediam da Zona Norte, poucas as que saíam de Copacabana, Botafogo, Laranjeiras, Leblon e 
Nara Azevedo e Luiz Otávio Ferreira

Ipanema. Algumas vinham de Ramos, Rocha, Cascadura e Nova Iguaçu. A maioria, entretanto, provinha da Tijuca, Andaraí, Méier, Cachambi, Rio Comprido, Praça da Bandeira, Maracanã, Engenho Novo, Vila Isabel, Grajaú, Estácio, São Cristóvão: proximidades da Mariz de Barros. Eram filhas de médicos, e outros profissionais liberais, de funcionários públicos e pessoas do comércio. Em geral, adquiriam o gosto pelo magistério em casa, com as mães, também professoras. Escolhiam a profissão porque raras eram as oportunidades de trabalho fora do lar. (Vidal, 2001:38-39)

A Escola de Professores foi incorporada, em 1935, à recém criada Universidade do Distrito Federal (UDF), sob a denominação de Faculdade de Educação assumindo a responsabilidade pela concessão da "licença magistral" para os portadores da "licença cultural", obtida em outros cursos universitários oferecidos pela universidade. (Taruni, 2000:73) Com a extinção daquela universidade, em 1939, e a anexação de seus cursos à Universidade do Brasil, a Escola de Professores retornou ao Instituto de Educação, agora não mais como um curso de nível superior.

Experiência semelhante de formação de professores em cursos de nível superior foi desenvolvida na mesma época em São Paulo, sob a liderança de Fernando Azevedo. Em 1933, a tradicional Escola Normal paulistana foi transformada no Instituto de Educação Caetano de Campos e, seguindo o modelo da Escola de Professores do Instituto de Educação, começou a oferecer cursos de formação de professores primários, cursos de formação pedagógica para professores secundários, além de cursos de especialização para diretores e inspetores. Com a fundação da Universidade de São Paulo (USP), em 1934, o Instituto de Educação, incorporado à estrutura universitária, assumiu a responsabilidade de capacitar pedagogicamente os alunos das diversas seções da Faculdade de Filosofia, Ciências e Letras. Em 1938, o Instituto de Educação se desvinculou e o curso 
Modernização, políticas públicas e sistema de gênero no Brasil

normal retornou a sua condição original de curso de formação profissional de nível secundário. Como aconteceu no Rio de Janeiro, o "curto verão" da escola normal paulistana de nível superior também atraiu uma clientela predominantemente feminina oriunda das classes médias urbanas, mas também um número significativo de moças provenientes de pequenas cidades do interior paulista. (Evangelista, 2001)

A incorporação da escola normal à universidade foi decisiva para o avanço da escolarização e da profissionalização feminina. Inaugurou-se com essa experiência o ingresso de mulheres no ensino superior em decorrência de uma ação deliberada do poder público, no caso, as autoridades responsáveis pela educação no Distrito Federal e no Estado de São Paulo. A presença das "normalistas" na universidade se fará notar de forma crescente no decorrer das décadas de 1940 e seguintes, sobretudo nas Faculdades de Filosofia, Ciências e Letras. Estas constituíram um lócus privilegiado de educação e profissionalização feminina, inclusive em cursos de ciências, que representavam uma inovação institucional em relação às tradicionais faculdades de medicina, engenharia, agronomia e veterinária, nas quais predominavam os homens. A Faculdade de Filosofia, Ciências e Letras da Universidade de São Paulo constitui um exemplo notável desse processo. Quando somente um pequeno contingente de candidatos se apresentou ao primeiro exame vestibular, decidiu-se convocar os professores da rede pública estadual, que eram em sua maioria mulheres egressas das escolas normais. Na condição de comissionadas (que significava a dispensa das funções docentes sem prejuízo dos vencimentos), as "normalistas" ingressaram nos curso de ciências e humanidades, embora, legalmente, somente o ensino secundário habilitasse o acesso ao ensino superior. (Limongi, 1989) Tal estratégia foi mantida até o final da década de 1950, gerando muita polêmica entre os professores (Fernandes, 1966:262-263), mas produzindo uma situação imprevista: um número inédito de mulheres obteve 
diploma universitário e empreendeu uma carreira dedicada à pesquisa e ao ensino.

Se o magistério em suas diferentes modalidades e funções ofereceu uma real oportunidade de educação e profissionalização para as mulheres de classe média urbana, a falta de outras oportunidades, principalmente de escolarização em nível superior, deveu-se à forma esdrúxula como o ensino secundário estava organizado no país até o início dos anos 1930. Se a escola primária e a escola normal vinham sofrendo o impacto positivo da ação dos reformadores, o mesmo não ocorreu com a escola secundária. Sob a jurisdição do governo federal durante a Primeira República, o ensino secundário foi objeto de seguidas reformas, e de mais duas na era Vargas, uma em 1931 e outra em 1942. Todas as reformas empreendidas até 1925 visavam o aperfeiçoamento e a difusão do ensino secundário, com a superação do sistema de exame parcelados, que faziam desta etapa da escolarização apenas um preparatório para o ingresso no ensino superior. Não existia propriamente uma rede de escolas secundárias organizada nacionalmente. Como havia sido durante todo o Império, a única referência era o Colégio Pedro II que cumpria a função de estabelecimento-padrão. A escassez de estabelecimentos públicos de ensino definia o caráter altamente seletivo do ensino secundário que

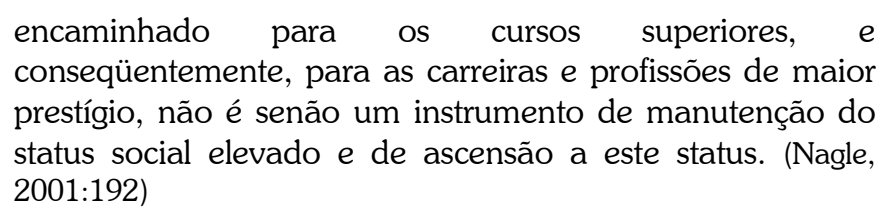
conseqüentemente, para as carreiras e profissões de maior prestígio, não é senão um instrumento de manutenção do status social elevado e de ascensão a este status. (Nagle, 2001:192)

O sentimento elitista do ensino secundário era tão arraigado que a reforma de 1925 foi duramente combatida, já que "do ponto de vista dos estudantes e das famílias, em particular, não havia clima para se deixar de pensar no secundário, principalmente, como mecanismo de ascensão social". (Id.) 
Modernização, políticas públicas e sistema de gênero no Brasil

Mesmo para os militantes mais engajados a destinação social do ensino secundário deveria ser a preparação das novas "elites" intelectuais, empresarias e políticas. (Carvalho, 1998:246-247)

Essa mesma concepção norteou a Lei Orgânica do Ensino Secundário assinada pelo Ministro Gustavo Capanema em 1942: o sistema educacional deveria corresponder à divisão econômicosocial do trabalho, que incluía também a distinção por gênero. Desse modo, a cada classe ou grupo social deveria corresponder um tipo específico de escola coerente com as funções sociais atribuídas a cada um deles.

Teríamos assim, a educação superior, a educação secundária, a educação primária, a educação profissional e a educação feminina; uma educação destinada à elite da elite, outra educação para a elite urbana, uma outra para os jovens que comporiam o grande "exercito de trabalhadores necessários à utilização da riqueza potencial da nação" e outra ainda para as mulheres. (Schwartzman et alii, 2000:204215)

Neste modelo deveria haver uma distinção entre a escola secundária, que preparava para o acesso ao ensino superior (o famoso "clássico" para as carreiras em humanidades, e "científico" para as carreiras técnico-científicas) e outros tipos de escola, que preparavam o indivíduo para o mundo do trabalho fosse ele industrial, comercial, agrícola, escolar ou doméstico. No entanto, não obstante o viés elitista e como um efeito inesperado, a estruturação do ensino secundário favoreceu o acesso das mulheres a escola secundária. Primeiro, porque não havia restrição legal ou moral a freqüência feminina e, segundo, devido à vasta rede privada de ensino, que vinha se organizando desde a década de 1920 e se expandiu ainda mais nas décadas seguintes. A seletividade (inclusive a de gênero) do ensino secundário foi sendo posta em questão pela crescente demanda social proveniente das camadas médias e pobres dos grandes centros urbanos. (Sposito, 1984) Ao contrário do que se esperava, não 
houve intensificação da procura pelo ensino industrial e agrícola. Acompanhado em menor proporção pelo ensino comercial $e$ normal, cuja clientela era predominantemente feminina, o ensino secundário foi aquele que mais se expandiu. Tal crescimento decorreu da proliferação do ginásio, primeira etapa do ensino secundário, por meio do qual se obtinha o acesso ao colegial, subdividido em "clássico" e "científico", porta de entrada necessária para o ensino superior. (Nunes, 2000)

A exigência crescente por professores para o ensino secundário alimentou o ingresso feminino no curso superior, já que a licença para o exercício do magistério no ginasial e colegial exigia a licenciatura obtida somente nas faculdades de filosofia. $\mathrm{O}$ magistério no ensino secundário, e até mesmo no ensino primário, foi o ponto de partida para muitas carreiras universitárias empreendidas por mulheres.

\section{Comentários finais}

Para um contingente importante de mulheres, sobretudo as de classe média urbana, as experiências de escolarização proporcionada pelas políticas sociais e, mais especificamente, pelas políticas educacionais implantadas isoladamente a partir dos anos 1920, que efetivamente se institucionalizaram na chamada era Vargas, foram em larga medida responsáveis por importantes mudanças no sistema de gênero, especialmente no que diz respeito à inserção profissional de mulheres no mundo acadêmico e científico. Mesmo quando não tinham explicitamente a intenção de mobilizar as mulheres na direção de uma participação ativa na vida pública, ou até mesmo quando o objetivo explícito de tais políticas era o de mantê-las na esfera doméstica, a dinâmica contraditória da modernização, alterando padrões de sociabilidade, gerando novas expectativas individuais e familiares $e$ impondo novas demandas profissionais, criou condições para que as novas experiências de escolarização fossem sendo apropriadas e resignificadas pelas mulheres. 
Modernização, políticas públicas e sistema de gênero no Brasil

Duas décadas antes da Reforma Universitária de 1968, a partir da qual se verificou o ingresso de mulheres na universidade de maneira crescente e ininterrupta, iniciou-se um processo de reforma educacional que produziu modificações substantivas na escolarização feminina, abrindo, por conseguinte, inovadoras oportunidades de profissionalização. Criavam-se, assim, as condições institucionais para relativizar a concepção de que as mulheres deveriam seguir uma profissão adequada - a boa profissão - às qualidades naturais femininas. As mudanças no âmbito do sistema escolar, combinadas com as transformações sociais mais largas, contribuíram para a redefinição dos papéis sociais femininos, mexendo, não sem ambigüidades, no grau de diferenças existentes entre homens e mulheres do sistema de gênero brasileiro. Pouco explorado pela historiografia, o tema da escolarização feminina é crucial para a compreensão do destino social das gerações de mulheres para as quais se descortinou o novo mundo da educação institucionalizada.

\section{Referências bibliográficas}

APPLE, Rima D. Mothers \& Medicine. A social history of infant feeding, 1890-1950. Maidson, The University of Wisconsin Press, 1987.

ARAÚJO, Rosa Maria Barbosa de. A vocação do prazer. A cidade e a familia no Rio de Janeiro republicano. Rio de Janeiro, Rocco, 1993.

AVELINO FILHO, George. Cordialidade e civilidade em Raízes do Brasil. Revista Brasileira de Ciências Sociais, vol. 5, n 12, fev. 1990.

BENCHIMOL, Jaime Larry. Pereira Passos: um Haussmann tropical. Rio de Janeiro, Secretaria Municipal de Cultura, Turismo e Esportes. Departamento Geral de Documentação e Informação Cultural, Divisão de Editoração, 1992.

BERMAN, Marshall. Tudo que é sólido desmancha no ar. A aventura da modernidade. São Paulo, Companhia das Letras, 1986.

BESSE, Susan. Modernizando a desigualdade: reestruturação da ideologia de gênero no Brasil (1914-1940). São Paulo, Edusp, 1999. 
BRESCIANI, Maria Stela. Cidade e história. In: OLIVEIRA, Lucia Lippi. (org.) Cidade: história e desafios. Rio de Janeiro, Ed. FGV, 2002.

BRUSCHINI, Cristina e AMADO, Tina. Estudos sobre a mulher $e$ educação: algumas questões sobre o magistério. Cadernos de Pesquisa (64), 1988, pp.4-13.

CARVAlHO, Marta Maria Chagas de. Molde Nacional e Fôrma Cívica: higiene, moral e trabalho no projeto da Associação Brasileira de Educação (1924-1931). Bragança Paulista, Edusf, 1998.

CUNHA, Luiz Antonio. $O$ ensino de ofícios nos primórdios da industrialização. São Paulo, Editora Unesp, 2000.

DERMARTINI, Zélia de Brito F. e ANTUNSA, Fátima Ferreira. Magistério primário: profissão feminina, carreira masculina. Cadernos de Pesquisa (86), 1993, pp.5-14.

EVANGELISTA, Olinda. Formar o mestre na universidade: a experiência paulista nos anos de 1930. Educação e Pesquisa, vol. 27, n 2, jun/dez 2001, pp.247-259.

FÁVERO, Maria de Lourdes Albuquerque e BRITTO, Jader de Medeiros. (orgs.) Dicionário de Educadores do Brasil. Rio de Janeiro, Editora UFRJ/MEC-Inep-Comped, 2002.

FERNANDES, Florestan. FFCL - USP: lições pedagógicas de uma crise. In: Fernandes, Florestan. Educação e Sociedade no Brasil. São Paulo, Dominius Editora/Edusp, 1966, pp.262-263.

FREYRE, Gilberto. Sobrados e Mucambos: decadência do patriarcado e desenvolvimento do urbano. $14^{\circ}$ ed. Revista, São Paulo, Global, 2003.

GOMES, Ângela de Castro. O primeiro Governo Vargas: Projeto Político e Educacional. In: MAGALDI, Ana Maria; ALVES, Claudia e GONDRA, José G. (orgs.) Educação no Brasil: história, cultura e política. Bragança Paulista, Edusf, 2003, pp.445-462.

HANNER, June Edith. Emancipação do sexo feminino. A luta pelos diretos da mulher no Brasil, 1850-1940. Florianópolis/Santa Cruz do Sul, Ed. Mulheres/Edunisc, 2003.

HOBSBAWN, Eric. A era dos impérios (1875-1914). Rio de Janeiro, Paz e Terra, 1988. 
Modernização, políticas públicas e sistema de gênero no Brasil

HOLANDA, Sérgio Buarque. Raízes do Brasil. São Paulo, Companhia das Letras, 1995.

LIMONGI, Fernando. Mentores e clientelas da Universidade de São Paulo. In: MICELI, Sergio. (org.) História das Ciências Sociais no Brasil. São Paulo, Vértice/Editora Revista dos Tribunais/Edesp, 1989, pp.111-187.

LOURO, Guacira Lopes e MEYER, Dagmar. A escolarização do doméstico. A construção de uma escola técnica feminina (19461970). Cadernos de Pesquisa (87), 1993.

MALUF, Marina e MOTT, Maria Lúcia. Recônditos do mundo feminino. In: SEVCENKO, N. (org.) História da Vida Privada no Brasil. Da belle époque à era do rádio. Vol. 3. São Paulo, Companhia das Letras, 1998. [Coordenador geral da coleção: Fernando A. Novais.]

MATTA, Roberto da. Carnavais, malandros e heróis: para uma sociologia do dilema brasileiro. Rio de Janeiro, Rocco, 1979.

MORSE, Richard. As cidades periféricas como arenas culturais. Estudos Históricos, vol. 8, n 16, Rio de Janeiro, 1995, pp.205-225.

NAGLE, Jorge. Educação e Sociedade na Primeira República. Rio de Janeiro, DP\&A, 2001.

NUNES, Clarice. O 'velho' e 'bom' ensino secundário: momentos decisivos. Revista Brasileira de Educação, $\mathrm{n}^{\circ}$ 14, mai/jun/jul/ago 2000, pp.45-50.

A Escola Redescobre a Cidade (Reinterpretação da modernidade pedagógica no espaço urbano carioca, 1910-1935). Rio de Janeiro, Universidade Federal Fluminense, 1993 [Tese apresentada ao Concurso para professor Titular em História da Educação].

PERROT, Michele. As mulheres ou os silêncios da história. Bauru-SP, Edusc, 2005.

. Sair. In: FRAISSE, Geneviève e PERROT, Michelle. (dir.) História das Mulheres no Ocidente. Volume 4 - O século XIX. Porto/São Paulo, Edições Afrontamento/Ebradil, s/d, pp.503-540 [Direção geral: George Duby e Michelle Perrot].

ROCHA, Heloisa Helena Pimenta. A educação sanitária com profissão feminina. Cadernos Pagu (24), Núcleo de Estudos de Gênero Pagu/Unicamp, janeiro-junho de 2005, pp.69-104. 
ROLEMBERG, Fúlvia. Educação formal, mulher e gênero no Brasil. Estudos Feministas, vol. 9, $\mathrm{n}^{\circ}$ 2, 2001, pp.521-527.

SCOTT, Joan. História das mulheres. In: BURKE, Peter. (org.) A escrita da história: novas perspectivas. São Paulo, Editora da Unesp, 1992.

SCHWARTZMAN, Simon; BOMENY, Helena Maria Busquet e COSTA, Vanda Maria Ribeiro. Tempos de Capanema. São Paulo, Paz \&Terra/FundaÇão Getúlio Vargas, 2000.

SEVCENKO, Nicolau. Introdução. O prelúdio republicano, astúcias da ordem e ilusões de progresso. In: SEVCENKO, N. (org.) História da Vida Privada no Brasil. Da belle époque à era do rádio. Vol. 3. São Paulo, Companhia das Letras, 1998, pp.7-47 [Coordenador geral da coleção: Fernando A. Novais].

[a]. A capital irradiante: técnica, ritmos e ritos do Rio. In: SEVCENKO, N. (org.) História da Vida Privada no Brasil. Da belle époque à era do rádio. Vol. 3. São Paulo, Companhia das Letras, 1998, pp.7-47 [Coordenador geral da coleção: Fernando A. Novais].

. Orfeu extático na metrópole: São Paulo, sociedade e cultura nos frementes anos 20. São Paulo, Companhia das Letras, 1992.

SPOSITO, Marília Pontes. O povo vai à escola. A luta popular pela expansão do ensino público em São Paulo. São Paulo, Loyola, 1984.

TARUNI, Leonor Maria. História da formação de professores. Revista Brasileira de Educação, n 14, mai/ago 2000.

TUPY, Ismênia Spinola Silveira. Resistência ou Transformações? Os números da educação feminina nos recenseamentos gerais da população. Estado de São Paulo, 1940-1970. Trabalho apresentado no XIII Encontro da Associação Brasileira de Estudos Populacionais. Ouro Preto, 2002.

VELHO, Gilberto. Estilo de vida urbano e modernidade. Estudos Históricos, vol.8, n 16, Rio de Janeiro, 1995, pp.227-234.

VELHO, Lea e PROCHAZKA, Maria Viviana. Mulheres na Ciência: No que o mundo da ciência difere dos outros mundos?. ComCiencia, Campinas, Brasil, 10 dez. 2003.

VIANNA, Luiz Jorge Werneck. A revolução passiva: iberismo $e$ americanismo no Brasil. Rio de Janeiro, Revan, 1997. 
Modernização, políticas públicas e sistema de gênero no Brasil

VIDAL, Diana Gonçalves e RODRIGUES, Rosane Nunes. A casa, a escola ou trabalho: o Manifesto e a profissionalização feminina no Rio de Janeiro (1920-30). In: Xavier, Maria do Carmo. (org.) Manifesto dos Pioneiros da Educação: um legado educacional em debate. Rio de Janeiro, Editora FGV, 2004, pp.89-112.

e PAULILO, Antônio. Projetos e estratégias de implementação da escola nova na capital do Brasil. In: MAGALDI, A. et alii (orgs.) Educação no Brasil: história, cultura e política. Bragança Paulista-SP, Edusf, 2003.

VIDAL, D.G. O exercício disciplinado do olhar: livros, leituras e práticas de formação docente no Instituto de Educação do Distrito Federal (1932-1937). Bragança Paulista-SP, Edusf, 2001.

"Educação Doméstica" e reformas da instrução pública do Distrito Federal. Cadernos de Pesquisa (99), nov. 1996

WEGNER, Robert. A conquista do oeste: a fronteira na obra de Sérgio Buarque de Holanda. Belo Horizonte, Ed. UFMG, 2000.

WERLE, Flávia Obino de Corrêa. Práticas de gestão e feminização do magistério. Cadernos de Pesquisa, vol. 35, no 126, set/dez 2005, pp.609-634. 